$R_{\text {ESEARCH }} \mathbf{P}_{\text {APER }} \longrightarrow$ FOOD SCIENCE.

e ISSN-2230-9403 - Visit us : www.researchjournal.co.in Volume 8 | Issue 1 |April, 2017 | 7-13 DOI : $10.15740 / \mathrm{HAS} / \mathrm{FSRJ} / 8.1 / 7-13$

\title{
Dietary survey as indicator of nutritional status of rural women of Bihar
}

\author{
VeEnita Kumari
}

\begin{abstract}
In every community, mothers and children are among the groups that are vulnerable to disease, disability and death. In recent years, there has been a remarkable upsurge of interest in the health and nutritional problems of women in the country. One of the major factors determining nutritional status of any community is food consumption. The study was conducted on 60 rural women from Bihar from two villages of Pusa block, Samastipur. The study was conducted to assess nutritional status of the respondents. The major findings of the study were that cereals and roots and tubers form the main diet of the respondents. Adequacy of cereals (131.36\%) and roots and tubers (115.0\%) is more than the RDA for the respondents of Birauli Khurd whereas for the respondents of Morsand Bahadura for cereals it was 127.33 per cent and roots and tubers 75.3 per cent of the RDA. The adequacy of energy and carbohydrate intake of the women of Birauli Khurd was more than that of the Morasand Bahadur while adequacy of other nutrients like protein, visible fat and total fat of the women of Morsand Bhadura was more than that of Birauli Khurd.
\end{abstract}

Key Words : Nutritional assessment, Dietary method, 24-hour recall method, Rural women

How to cite this article : Kumari, Veenita (2017). Dietary survey as indicator of nutritional status of rural women of Bihar. Food Sci. Res. J., 8(1): 7-13, DOI : 10.15740/HAS/FSRJ/8.1/7-13. 